\title{
Authigenic seep carbonates of the South China Sea - archives for geochemical cycling and geodynamic activity
}

\author{
YITING TSENG $^{1 *}$, ANDREA SCHRÖDER-RITZRAU ${ }^{2}$, \\ SAULWOOD LIN ${ }^{3}$, NORBERT FRANK ${ }^{2}$, GERHARD \\ BOHRMANN $^{1}$
}

${ }^{1}$ MARUM, Center of Environmental Sciences, University of Bremen, Germany ("correspondence: ytseng@marum.de) ${ }^{2}$ Institute of Environmental Physics, University Heidelberg, Germany

${ }^{3}$ Institute of Oceanography, National Taiwan University, Taiwan

A continuous 4.9-meter-long authigenic carbonate core was drilled on board R/V Sonne (SO266) at a water depth of $1347 \mathrm{~m}$, using the portable MARUM drilling system MeBo200. The core was drilled at the YAM cold seep field, offshore SW Taiwan, where active seepage is ongoing and a carbonate paved seafloor is located and exposed at the northern top of the accretionary ridge, known as Four Way Closure Ridge. 78 flare sites were observed over the pavement area $\left(\sim 40,000 \mathrm{~m}^{2}\right)$. Within the carbonate core, cemented shells, aragonites $(\sim 37.7 \%)$ and micrites $(\sim 62.3 \%)$ can be distinguished. Cemented matrixs and veins consist of mainly pure aragonite. Results from 52 aragonite U-Th dating show the absolute chronology from $2.5 \pm 0.18 \mathrm{ka}$ to $33.62 \pm$ $0.08 \mathrm{ka} \mathrm{BP}$, indicating the precipitation of carbonate via anaerobic oxidation of methane (AOM). AOM had been dominated at the site archiving the methane emanation variations throughout Late Quaternary. Calculated initial ${ }^{234} \mathrm{U} /{ }^{238} \mathrm{U}$ activity ratios $\left(\delta^{234} \mathrm{U}_{\mathrm{i}}\right)$ range between $128.8 \%$ o $1.8 \%$ and $153.4 \%$ $\pm 5.2 \%$ o (mean $140.4 \%$, std. dev. 5.3\%). They reveal marine $\delta^{234} \mathrm{U}$ values in the range from modern seawater $(146.8 \pm 0.1 \%$, [1]), as well as modern and last glacial values as documented e.g. in cold water corals (modern $146.7 \pm 0.4 \%$, last glacial $140.6 \pm 0.9 \%$, [2]). These results indicate, that we not only acquire the seepage chronology but also the direct correlation of paleoocean scenario from authigenic carbonate. Additionally, certain unconformities in the precipitation rings occurred at the depth of $338 \mathrm{cmbsf}$ (age $\sim 10$ to $26 \mathrm{ka}$ ) and $403 \mathrm{cmbsf}$ (age $\sim 20$ to $26 \mathrm{ka}$ ), showing cracks and the introduced of lateral aragonite vein precipitation. These structures imply the potential of tremendous physical forcing at a certain time and causing the non-continuous precipitation results.

[1]Andersen, M.B., et al. (2010) Geochem. Geophys. Geosyst. 11(12). [2]Wefing A.M. et al. (2017) Chem. Geol. 475: $140-148$. 